\title{
ТЕОРЕТИЧНІ ОСНОВИ ДАЛЬТОН-ПЛАНУ
}

\author{
Статтю присвячено опису педагогічної моделі Дальтон-плану у вітчизняній та зарубіжній науково-педагогічній \\ літературі. Зроблено спробу аналізу теоретичних основ Дальтон-плану. \\ Ключові слова: Дальтон-план, система навчання, індивідуалізачія навчання, індивідуальний контроль праці. \\ Статья посвящена описанию педагогической модели Дальтон-плана в отечественной и зарубежной научно- \\ педагогической литературе. Сделана попьтка анализа теоретических основ Дальтон-плана. \\ Ключевые слова: Дальтон-план, система обучения, индивидуализация обучения, индивидуальный контроль работыл. \\ The article is devoted to the description of the Dalton plan pedagogical model in the Ukrainian and foreign scientific \\ pedagogical literature. The Dalton Plan theory is analyzed. \\ Key words: Dalton plan, system of education, individualized education, separate work control.
}

Незважаючи на низку досліджень, виконаних у межах історії педагогіки, психології, методики викладання Дальтон-план, або Дальтонський лабораторний план, досить рідко ставав предметом спеціального наукового аналізу. Під час вивчення теоретичних досліджень зарубіжних та вітчизняних учених характерним $є$ те, що педагогічна модель Дальтон-плану, а саме його аспекти набули популярності серед західноєвропейських та американських педагогів. Вітчизняна наукова література в межах педагогіки має обмежений обсяг інформації з теми дослідження. Дальтон-план донедавна згадувався у вітчизняній літературі лише як буржуазна педагогічна теорія, яку було піддано гострій критиці та засудженню після ііі впровадження на території колишнього Радянського Союзу на початку XX-го ст.

До історіографічних праць, що уможливлюють аналіз ставлення як українських, російських, американських і британських учених до досліджуваної проблеми, належать історико-педагогічні роботи Е. Дьюї, С. Гончаренка, І. Лікарчука, О. Сухомлинської, В. Хатфільд, М. Хольт, М. Ярмаченка, а також підручники з історії педагогіки А. Піскунова, М. Шабаєвої, М. Левківського. На рівні дисертаційних праць цю проблему вивчали Д. Лагер, О. Гусєва, О. Барило.

Mета статmi - здійснити аналіз Дальтон-плану як ефективної педагогічної моделі у вітчизняній і зарубіжній науково-педагогічній літературі та визначити його теоретичні основи.

Ретельно розглядаючи Дальтон-план, ми вважаємо правомірним насамперед звернутися до вивчення довідково-енциклопедичної літератури.

Отже, проаналізувавши характеристики Дальтон-плану в довідково-енциклопедичній літературі, маємо підстави зробити припущення, що вітчизняні джерела єдині у визначенні того, що: 1) це система навчання або організації навчально-виховної роботи; 2) назва Дальтон-план пішла від м. Дальтон, де вперше було апробовано Дальтонський лабораторний план на базі місцевої школи в 1919 р.; 3) засновницею Дальтон-плану є американський педагог О. Паркхерст; 4) Дальтон-план побудовано за принципом індивідуалізованого навчання; 5) Дальтон-план передбачає характерний розподіл навчального матеріалу та індивідуальний облік праці; 6) Дальтон-план надає змогу пристосовувати темп навчання до можливостей учнів; 7) серед переваг, якими характеризується Дальтон-план, ми можемо визначити свободу розумову та моральну, формування самостійності, ініціативи, почуття відповідальності за взяті на себе зобов'язання, пошук раціональних методів роботи [2, с. 114].

У 20-і роки XX ст. Дальтон-план здобув широкого визнання в Англії, де його принципи були модифікованим у «Горвард-план», що спрямувався на досягнення максимальної гнучкості у виборі учнями навчальних курсів у межах класу при збереженні обов’язкового освітнього стандарту. В українській школі теж робилися спроби запровадити Дальтон-план, але за умови зменшення його індивідуалізації. 3 цією метою було розроблено бригадно-лабораторний метод навчання [3, с. 162].

О. Паркхерст подає такий опис Дальтонського лабораторного плану. Умови, створені Дальтонським лабораторним планом, у яких учень, для того, щоб ними користуватись, мимохіть функціонує як член соціальної спільноти. Його спільнота або приймає, або заперечує відповідно до його функціонування $[8$, с. 84]. «Власне кажучи, це не схема реорганізації освіти, яка поєднує дві діяльності навчання та викладання, - зауважує О. Паркхерст.За їх розумного застосування створюються умови, які надають можливості вчителю вчити, а учню навчатися»,$[9$, с. 34].

Дальтон-план, за Е. Дьюї, характеризуємо як спробу організації школи, яка поєднала потреби сучасної освіти в умовах загальноосвітньої школи, у якій «наближена до життя» якість плану дозволить учням трансплантувати поведінку та навички поза стінами класної кімнати без будь-якого втручання зі сторони вчителя [7, с. 102].

Розглядаючи структуру Дальтон-плану, можемо визначити такі структурні елементи: лабораторії, кваліфікований вчительський склад, розподіл навчального матеріалу та самостійність у виконанні завдань. 
Лабораторії. Цей підрозділ передбачає організацію лабораторій, обладнаних для кожного предмету. Слід зауважити, що замість традиційного шкільного кабінету, який використовується для лабораторних занять 3 того чи іншого предмету учнями всіх шкільних ступенів, О. Паркхерст запропонувала лабораторії, які використовувалися б одним вчителем та певною віковою групою учнів. Відвідування учнями спеціальих предметних лабораторій передбачає економію шкільного обладнання. До особливих рис Дальтон-лабораторії належать наявність не тільки довідкової та навчальної літератури а й додаткової, присутності учителя в лабораторії у визначений період під назвою «лабораторний час». Дальтон-план не передбачає також зміни вчителів-предметників щороку, оскільки вважається, що часта зміна вчителів негативно впливає на ставлення учнів до предмета, після чого його робота над тим чи іншим предметом щороку змінюється, але в супроводі одного вчителя.

Учительський склад. Дальтон-вчителів характеризує гнучкість у відхиленні від обраного освітнього маршруту, свобода у виборі чому навчати, де і як. Вчитель не є контролюючою особою, не головним джерелом інформації, а частиною освітнього простору. Учителю відводиться роль помічника, організатора, координатора. При підсумковому звіті перед вчителем, недостатньо якісно виконана учнем робота підлягає обговоренню. Завданням Дальтон-вчителя є створення умов, за яких клас міг би здійснювати роботу без його участі. Мета організації навчання за Дальтон-планом - це створення умов самостійного пошуку, орієнтації в інформаційному просторі.

Розподіл навчального матеріалу. Навчальний матеріал розподілено на блоки відповідно до кількості навчальних місяців. Кожним учнем підписується контракт, за умовами якого він сам бере на себе відповідальність стосовно виконання завдань з кожного предмета. Контракт передбачає часові межі виконання завдань та вид роботи. Темпи та обсяг виконання завдань регулюються самим учнем. У картках розподілено навчальний матеріал, чітко прописано теми, рекомендовано джерела інформації, способи перевірки й оцінювання, а також час та місце отримання консультацій. Здійснюється щоденний облік виконаної роботи, спланованої самим учнем, який допомагає вчити учнів самоперевірці, раціонально витрачати час, розвивати відчуття часу, розподіляти свою діяльність.

Самостійність у виконанні завдань. Кожне завдання передбачає засвоєння достатнього обсягу інформації. Матеріал, який включено до завдання, обов'язково складається з урахуванням його самостійного опанування. Завдання виконуються учнями самостійно, у присутності та за сприяння педагога. Години, проведені учнями за самостійною роботою прийнято вважати головними.

Окрім системи навчання, в основу якої покладено Дальтон-план, педагоги розглядають також форму навчання. На думку А. Кузьмінського, Дальтон-план $є$ основою однієї 3 шести форм організації навчання. Зупинимось на дальтон-планівській та бригадно-лабораторній. Слід звернути увагу, що остання форма $\epsilon$ попередньою, але зі зміненим напрямком діяльності учнів від індивідуальної до колективної, яка була активно впровадженою в 20-ті рр. у вітчизняній освіті, але завдяки зміненню основного складника дальтон-планівської форми, що виступає в індивідуальному підході на колективний, ця форма втратила свою ефективність, піддалася критиці та різкому засудженню.

Педагог характеризує дальтон-планівську форму організації навчання як форму навчання, яка виникла під впливом філософської концепції екзистенціалізму 3 метою формування у дітей ініціативності, самостійності, винахідливості, діловитості. Технологія навчання полягала: в розподілі змісту навчального матеріалу з кожної дисципліни на частини (блоки), отриманні кожним учнем індивідуального завдання у формі плану, у самостійному його виконанні, звітові з отриманням певної кількості балів, після чого $є$ можливим отримання наступного завдання. Учитель відігравав роль організатора, консультанта. Переведення учнів відбувався не по закінченню навчального року, а залежно від рівня оволодіння програмним матеріалом (3-4 рази на рік).

Таке навчання, - уважав А. Кузьмінський, - сприяло формуванню самостійності, ініціативності, позитивно впливало на інтелектуальний розвиток особистості. Разом з тим автор критично ставиться до навчання, яке розвивало «нездорове» суперництво, індивідуалізм, та це відповідало формуванню менталітету співучасників ринкової економіки [4, с. 143].

На противагу класно-урочній формі навчальної роботи на початку XX ст. Б. Ссипов розглядав Дальтон-план в основі нової організаційної форми навчання, яка набула найбільшої популярності. Педагог підкреслює індивідуалістичність, як одну з умов ефективності розглядуваної форми навчання. Новизну такої форми організації навчання автор убачав у тому, що «основну роботу виконував кожен учень індивідуально за розробленими педагогами завданнями в спеціально устаткованих, відповідно до кожного навчального предмета, кабінетах і лабораторіях. Кожен учень міг працювати своїми темпами й організовувати свій час за своїм бажанням». Б. Єсипов справедливо вказує на те, що «спокусившись тим, що Дальтон-план надає величезне місце активній самостійній роботі учнів, деякі радянські педагоги некритично переносили цю форму роботи в радянські школи» [1, c. 114]. 
Окрім форми організації навчання, системи навчання, Дальтон-план може розглядатися і як педагогічна технологія. Ми наведемо кілька визначень сутності терміна «педагогічна технологія», який останнім часом став достатньо популярним поміж представників педагогічної науки.

Педагогічна технологія - це продумана в усіх деталях модель спільної педагогічної діяльності 3 проектування, організації i проведення навчального процесу 3 безперечним забезпеченням комфортних умов для учнів та вчителя (В. Монахов).

Будь-яка сучасна педагогічна технологія становить сукупність досягнень сучасної педагогічної науки, практичних знань, традиційних і прогресивних методів навчання та викладання.

У дисертації О. Гусєва розглядає Дальтон-план як дидактично виправдану технологію, підвищений інтерес до якої відбувся після реформ соціальної, економічної та освітньої сфер. Автор інтерпретує вищевказану технологію як інноваційну, звернення до якої зумовлено: переходом до нової освітньої парадигми, необхідністю підвищення якості освіти через індивідуалізацію навчання та формування самостійності мислення, адаптованістю до навчальних предметів, актуальністю форми в підготовці до іспитів.

О. Гусєва дійшла висновку, що Дальтон-план - технологія, яка відповідає вимогам сучасної освіти, оскільки належить до технології індивідуалізації навчання. Використання Дальтон-плану сприяє індивідуальній корекції знань, розвитку самостійного мислення, покращення навчальної мотивації, розвитку пізнавальних інтересів учнів, формуванню таких якостей особистості, як самостійність, відповідальність та працелюбність.

В. Кукушин указує на близькість Дальтон-технології з методом проектів. Водночас у своїй роботі автор висловлює сумнів щодо передчасного визначення «Дальтону» як технології, незважаючи навіть на те, що визначились основні ознаки: мету, похідні ідеї, зміст, форми, системи діяльності вчителів та учнів. На думку автора, технологія має великі можливості для реалізації ідеї особистісного розвитку дитини, навіть в умовах класно-урочної системи. Важливе ставлення американського педагога О. Паркхерст до навчання. Вивчивши методи викладання в американських школах, О. Паркхерст дійшла висновку, що в них відбувається насильне навчання, що стримує природне бажання дітей вільно висловлювати свої думки, ставити питання, грати. Розроблений О. Паркхерст «Лабораторний план» мав на меті навчити дітей жити в соціумі, розвивати розум, тіло та дух.

О. Паркхерст наголошує, що «Дальтон-план швидше робить акцент на важливості способу життя дитини під час виконання ним своєї роботи і на її поведінці як члена суспільства, а не на предметах його навчальної програми. Саме загальна сума цього подвійного досвіду визначає іiі характер і iï знання» $[9$, c. 24].

В основу технології «Лабораторний план» покладено ідею поєднання діяльності вчителя й учня заради досягнення індивідуалізованих цілей навчання. Особливу увагу приділено саме індивідуалізації навчання, оскільки через неї насамперед забезпечується технологія особистісного розвитку дитини.

Отже, основну ідею Дальтон-плану, за автором педагогічної моделі О. Паркхерст, тлумачимо як заміну працюючого надважкого механізму на просту реконструкцію шкільної процедури, за якою учні відчували б не лише більше свободи, а й різницю в оточенні, яке більш адаптоване до різних секцій їхнього навчання [9, с. 13].

Усе це надає змогу висловити нам припущення про те, що Дальтон-план розглядають як систему, форму та технологію навчання, яка забезпечує індивідуальний розвиток дитини, вдосконалення соціального досвіду за рахунок оволодіння навичками співробітництва, відповідальності і самостійності в навчально-пізнавальній діяльності.

Автор вбачає вихідні теоретичні позиції Дальтон-технології в такому: Дальтон-план становить поєднання кабінетного навчання 3 навчальним процесом, заснованим на трьох принципах: свобода, співробітництво та самостійність. Принципи поєднані одним головним - принципом гуманізму. Проаналізовані вище позиції приймаємо за сутність філософії Дальтон-плану.

\section{Література}

1. Есипов Б. П. Педагогика: учебник для педагогических училищ (на украинском языке) / Б. П. Есипов, Н. К. Гончаров - Х. : Радянська школа, 1947. - 410 с. 2. Гончаренко С. У. Український педагогічний енциклопедичний словник. / С. У. Гончаренко. - [ 2-ге вид.; доп. і випр.]. - Рівне : Волинські обереги, 2011. 552 с. 3. Енциклопедія освіти / Акад. пед. наук України; головний ред. В. Г. Кремінь. - К. : Юрінком Інтер, 2008. - 1040 с. 4. Кузьмінський А. І. Педагогіка : [підручник] / А. І. Кузьмінський, В. Л. Омеляненко - К. : Знання-Прес, 2003. - 418 с. - (Навчально-методичний комплекс з педагогіки). 5. Педагогические технологии : [учеб. пособ. для студ. пед. спец.] / под. общ. ред. В. С. Кукушина. - Ростов-на-Дону : Феникс, 2010. - 333с. ; ил.- (Педагогическое образование). 6. Педагогічний словник / за редакцією дійсного члена АПН України Ярмаченка М. Д. - К. : Педагогічна думка, 2001. 7. Dewey, Evelyn. The Dalton Laboratory Plan. New York: Dutton, 1922. 8. Holt, Mara. «Dewey and the «Cult of Efficiency»: Competing Ideologies in Collaborative Pedagogies of the 1920s» Journal of Advanced Composition 14.1(1994):84-90. 9. Parkurst, Helen. Education on The Dalton Plan. New York: Dutton, 1922. 